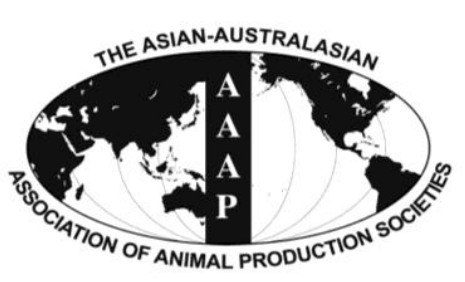

Open Access

Asian Australas. J. Anim. Sci.

Vol. 27, No. 12 : 1705-1711 December 2014

http://dx.doi.org/10.5713/ajas.2014.14089

www.ajas.info

pISSN 1011-2367 elSSN 1976-5517

\title{
In vitro and Lactation Responses in Mid-lactating Dairy Cows Fed Protected Amino Acids and Fat
}

\author{
I. S. Nam ${ }^{1,2}$, J. H. Choi ${ }^{1,3}$, K. M. Seo ${ }^{1}$, and J. H. Ahn ${ }^{1, *}$ \\ ${ }^{1}$ Department of Animal Life and Environment Science, Hankyong National University, Ansong 456-749, Korea
}

\begin{abstract}
The objective of this study was to evaluate the effect of ruminally protected amino acids (RPAAs) and ruminally protected fat (RPF) supplementation on ruminal fermentation characteristics (in vitro) and milk yield and milk composition (in vivo). Fourteen mid-lactating Holstein dairy cows (mean weight $653 \pm 62.59 \mathrm{~kg}$ ) were divided into two groups according to mean milk yield and number of days of postpartum. The cows were then fed a basal diet during adaptation ( $2 \mathrm{wk})$ and experimental diets during the treatment period (6 wk). Dietary treatments were i) a basal diet (control) and ii) basal diet containing $50 \mathrm{~g}$ of RPAAs (lysine and methionine, 3:1 ratio) and $50 \mathrm{~g}$ of RPF. In rumen fermentation trail (in vitro), RPAAs and RPF supplementation had no influence on the ruminal $\mathrm{pH}$, dry matter digestibility, total volatile fatty acid production and ammonia- $\mathrm{N}$ concentration. In feeding trial (in vivo), milk yield $(\mathrm{p}<0.001), 4 \%$ fat corrected milk $(\mathrm{p}<0.05)$, milk fat $(\mathrm{p}<0.05)$, milk protein $(\mathrm{p}<0.001)$, and milk urea nitrogen $(\mathrm{p}<0.05)$ were greater in cows fed RPAAs and RPF than the corresponding values in the control group. With an index against as $0 \%$, the rates of decrease in milk yield and milk protein were lower in RPAAs and RPF treated diet than those of basal diet group $(\mathrm{p}<0.05)$. In conclusion, diet supplemented with RPAAs and RPF can improve milk yield and milk composition without negatively affecting ruminal functions in Holstein dairy cows at mid-lactating. (Key Words: Rumen Protected Amino Acids, Rumen Protected Fat, Fermentation, Milk Yield)
\end{abstract}

\section{INTRODUCTION}

Feed additives such as methionine or fat are an appropriate method to increase milk yield and milk composition. Dairy cows needs optimum energy sources through diet formulation to increase their performance as dairy farmers in Korea and many other countries generally receive a milk price based on milk yield and fat content. Dairy cows need the same essential amino acids (AA) like methionine (Met) or lysine (Lys) as nonruminants (Fuller et al., 1989). Progress in the field of individual AA nutrition of dairy cows has often been studied. Amino acids are a nutritional source for increasing protein content in milk and milk yield of dairy cows. However, Lys and Met have been determined as the most limiting AA for lactating cows fed a variety of corn-based diets (Schingoethe et al., 1988; Izumi

\footnotetext{
* Corresponding Author: J. H. Ahn. Tel: +82-31-670-5124, Fax: +82-31-670-5129, E-mail: jhahn@hknu.ac.kr

${ }^{2}$ GRRC, Hankyong National University, Ansong 456-749, Korea.

${ }^{3}$ Nutritional Resource Research Institute, Seoul 137-887, Korea.

Submitted Feb. 7, 2014; Revised Apr. 7, 2014; Accepted Jul. 8, 2014
}

et al., 2000).

Non-protected dietary fat reduces forage consumption and inhibits rumen fermentation (Bines et al., 1978). Therefore, ruminally protected fat (RPF) as feed supplementation has been examined in many studies (Macleod et al., 1977; Yang et al., 1978; Sharma et al., 1978; Wrenn et al., 1978).

Chalupa et al. (1986), Mattias et al. (1982) and Veira et al. (1991) reported that the aims of supplementing RPFs to dairy cattle were to increase milk yield, milk fats, arginine and glutamine acid concentrations in blood and to enhance nitrogen retention. Previous studies indicated the different roles of supplementation of ruminally protected amino acids (RPAAs) and RPFs of dairy cows. Supplementing RPAAs and RPFs have many positive effects on lactating performance except decreasing protein (when added RPFs only) and fatty acids (when added RPAAs only) contents in milk (Palmquist and Conrad, 1978; Mattias et al., 1982; Donkin et al., 1989; Robinson et al., 1992). Addition of RPAAs and RPFs together into generally used feed may recover those above problems. However, there are no 
reports regarding the effects of supplementing RPAAs and RPF together on in vitro ruminal fermentation and lactation responses in mid-lactating Holstein dairy cows.

Therefore, our study consisted with two experiments in which RPAAs and RPF have been supplemented into the diet to evaluate the rumen fermentation and lactation performances in mid-lactating Holstein dairy cows. First experiment (in vitro) was conducted to evaluate the effects on fermentation characteristics by supplementation of RPAAs and RPF. Second experiment (in vivo) was to compare the changes in milk yield and milk composition between cows fed with supplemented RPAAs and RPF and cows fed without supplemented RPAAs and RPF.

\section{MATERIALS AND METHODS}

\section{Rumen fermentation, in vitro}

Ruminal fluid was collected from a ruminally fistulated Holstein-Friesian cow fed $53.3 \%$ of total mixed ratio, $16.7 \%$ of timothy $10 \%$ or rice straw and $20 \%$ of concentrate supplement once per day. Immediately following collection it was squeezed through four layers and eight layers of cheesecloth into an Erlenmeyer flask with an $\mathrm{O}_{2}$-free headspace. The flask was not disturbed for $30 \mathrm{~min}$ incubation in a $39^{\circ} \mathrm{C}$ water bath to permit feed particles to rise to top of flask. Particle-free ruminal fluid was anaerobically transferred to a buffer ( $\mathrm{pH} 7.0$ ) containing 7.5 $\mathrm{g}$ of $\mathrm{NaHCO}_{3}, 0.824 \mathrm{~g}$ of $\mathrm{Na}_{2} \mathrm{HPO}_{4}$ anhydrous, $0.31 \mathrm{~g}$ of $\mathrm{KH}_{2} \mathrm{PO}_{4}$ anhydrous, $0.03 \mathrm{~g}$ of $\mathrm{MgSO}_{4} 7 \mathrm{H}_{2} \mathrm{O}, 3.25 \mathrm{mg}$ of $\mathrm{CaCl}_{2}$ anhydrous, $2.5 \mathrm{mg}$ of $\mathrm{MnCl}_{2} 4 \mathrm{H}_{2} \mathrm{O}, 0.25 \mathrm{mg}$ of $\mathrm{COCl}_{2} 6 \mathrm{H}_{2} \mathrm{O}$ and $2.0 \mathrm{mg}$ of $\mathrm{FeSO}_{4} 7 \mathrm{H}_{2} \mathrm{O} / \mathrm{L}$. Ruminal fluid and buffer were mixed (1:1 ratio), and $200 \mathrm{ml}$ rumen samples (100 $\mathrm{mL}$ ruminal fluid $+100 \mathrm{~mL}$ buffer) were anaerobically transferred to $250 \mathrm{~mL}$ bottles containing $4 \mathrm{~g}$ of control and treatment diet samples. The bottles were capped with butyl-rubber stoppers containing gas regulator and placed at shaking incubator (Vision, Deajeon, Korea) at $39^{\circ} \mathrm{C}, 100 \mathrm{rpm}$. Samples were incubated at 3, 6, 12, 24, and $48 \mathrm{~h}$. Experimental diet was ground to pass through a $2 \mathrm{~mm}$ screen using a Wiley Mill. $2.71 \%$ of RPLys and $0.90 \%$ RPMet (3:1 ratio) and $3.62 \%$ of RPF were then mixed. The chemical composition of experimental diets was analyzed as shown in Table 1.

\section{Lactation responses, in vivo}

Fourteen multiparous (2nd to 3rd lactation) Holstein dairy cows (mean body weight, $653 \pm 62.59$ ) of mid-lactating stages were fed as shown in Table 1 . The cows were divided into two groups of seven cows each according to mean milk yield (35 kg/d) and mean number of days postpartum (145 d). They were fed a basal diet during adaptation period (2 wk) and the basal diet with RPAAs and RPF during treatment periods $(6 \mathrm{wk})$.

The ingredients and chemical composition of the experimental diet are shown in Table 1. Dietary treatments were i) the control (basal diet; no addition of RPAAs and RPF), and the treatment group fed basal diet with $50 \mathrm{~g}$ of RPAAs and $50 \mathrm{~g}$ of RPF twice a day (total $100 \mathrm{~g}$ of each RPAAs and RPF/d). Dairy dry matter intake (DMI) was recorded and water was provided ad libitum.

Cows were milked twice daily starting at 06:00 and 18:00 h, and milk yield was recorded weekly and milk samples were taken weekly from each cow during the experimental period (6 wk). Milk samples were refrigerated

Table 1. Ingredient and chemical composition of experimental diets fed for lactating cows (in vitro, in vivo \%, DM basis)

\begin{tabular}{lccccc}
\hline \multirow{2}{*}{ Composition $(\%)$} & \multicolumn{3}{c}{ Ingredients $^{1,2}$} \\
\cline { 2 - 6 } & Concentrate mix $^{3}$ & Beet pulp & Cotton seed & Oat & Alfalfa hay \\
\hline Dry matter & 89.50 & 89.29 & 90.36 & 94.79 & 82.86 \\
Crude protein & 21.33 & 10.66 & 20.27 & 9.45 & 16.14 \\
Crude fat & 5.62 & 0.94 & 21.94 & 3.57 & 2.41 \\
Crude fiber & 10.34 & 25.80 & 34.06 & 35.43 & 41.11 \\
Crude ash & 6.07 & 6.09 & 6.02 & 5.73 & 5.85 \\
NDF & 50.07 & 56.42 & 55.42 & 72.01 & 54.30 \\
ADF & 13.85 & 29.90 & 45.79 & 44.07 & 46.08 \\
NFE & 46.14 & 45.81 & 8.07 & 40.61 & 27.34 \\
Mixing rate & 42.19 & 7.07 & 5.72 & 31.50 & 13.53 \\
\hline
\end{tabular}

DM, dry matter; NDF, neutral detergent fiber; ADF, acid detergent fiber; NFE, nitrogen free extract; RPAAs, ruminally protected amino acids; RPF, ruminally protected fat; RPLys, ruminally protected lysine; RPMet, ruminally protected methionine.

${ }^{1}$ In vitro study: control group incubated $4 \mathrm{~g}$ of basal diet only (no addition of RPAAs and RPF), and the treatment group incubated basal diet with $2.71 \%$ RPLys and $0.90 \%$ RPMet (3:1 ratio) and 3.62\% RPF.

${ }^{2}$ In vivo study: control group fed basal diet only (no addition of RPAAs and RPF), and the treatment group fed basal diet with $50 \mathrm{~g}$ of RPAAs (50\% of RPLys and RPMet, [3:1 ratio]) and $50 \mathrm{~g}$ of RPF (98\% of RPF) twice a day (total $100 \mathrm{~g}$ of each RPAAs and RPF/d).

${ }^{3}$ Commercial concentrate which was manufactured for lactating cows producing 30 to $40 \mathrm{~kg}$ milk per day.

${ }^{4}$ Containing $200 \mathrm{mg}$ manganese, $100 \mathrm{mg}$ cobalt, 4,000 mg sulfur, $150 \mathrm{mg}$ iodine, 2,000 mg iron, $100 \mathrm{mg}$ zinc, $100 \mathrm{mg}$ copper, $50 \mathrm{mg}$ nickel, $2,000 \mathrm{mg}$ calcium, 3,000 mg magnesium, $40 \mathrm{mg}$ selenium.

${ }^{5}$ The rate of forage and concentrate was $6: 4$. 
at $4^{\circ} \mathrm{C}$ for the analysis of milk composition.

\section{Chemical analysis}

In vitro samples $(50 \mathrm{~mL})$ were removed through the butyl rubber stopper using a $60 \mathrm{~mL}$ syringe at $0,3,6,12,24$, and $48 \mathrm{~h}$ of incubation. Samples were immediately centrifuged $\left(14,000 \times \mathrm{g}\right.$ at $4^{\circ} \mathrm{C}$ for $\left.15 \mathrm{~min}\right)$, and supernatant fluids were stored at $-20^{\circ} \mathrm{C}$ for analysis. Cell wall contents (neutral detergent fiber and acid detergent fiber) were estimated as per the method of Goering and Van Soest (1970). Nitrogen free extract, crude protein, ether extract, and total ash contents of diets were analyzed according to AOAC (1984) procedures. The $\mathrm{pH}$ values of fermented samples were determined according to the method of Briggs et al. (1957). In vitro dry matter digestibility (DMD) was determined using the method of Tilley and Terry (1963). The total volatile fatty acid (VFA) in samples of supernatant fluid were measured by a gas chromatograph (Hewlett Packard 6890, USA), (column temperature: $120^{\circ} \mathrm{C}$, injector temperature: $265^{\circ} \mathrm{C}$, detector temperature: $240^{\circ} \mathrm{C}$ ) equipped with an autosampler and closslinked polyethylene glycol, $\varnothing 0.53 \mathrm{~mm} \times 30 \mathrm{~m}$ size FFAP column (Hewlett Packard, USA). The concentration of ammonia-N was measured by a color-metric method Chaney and Marbach (1962).

Milk samples refrigerated at $4^{\circ} \mathrm{C}$ were analyzed for fat, protein and MUN by automatic milk analyzer (Automatic IR 4000/5000 Milk Analyzer, Foss Electric, Hillerød, Denmark).

\section{Statistical analysis}

All data were analyzed using the general linear models of Statistical Analysis System (SAS, 1996). The last significant differences between means were calculated using a $t$-test procedure.

\section{RESULTS AND DUSCUSSION}

\section{In vitro rumen fermentation}

The effects of adding of RPAAs and RPF to the diet on ruminal $\mathrm{pH}$ of in vitro fermentation are shown in Table 2.
The $\mathrm{pH}$ value measurement can be used as a tool to evaluate the fermentation in the rumen (Kumar et al., 2013). Ruminal $\mathrm{pH}$ was not affected by supplementing RPAAs and RPF in the diet $(\mathrm{p}>0.05)$. In present study, the $\mathrm{pH}$ is similar between control and treatment, this observation is in agreement with previous in vivo studies (Sutton et al., 1983; Canale et al., 1990; Wang et al., 2004), which reported that pH was not significantly affected by supplementing RPAAs or RPF.

Supplementation of RPAAs and RPF also did not affect ( $>0.05$ ) the DMD compared to control (Table 2). Hill and West (1991) and Canale et al. (1990) observed that RPAAs and RPF supplementation of ruminant diets did not affect DMD. Ngidi et al. (1990) reported that RPF supplementation of beef finishing diets did not affect DMD or energy digestibility. Our study is in agreement with above results and indicated that the RPAAs and RPF supplementation did not influence $\mathrm{pH}$ and DMD in the rumen.

Results of the in vitro fermentation on total VFA and ammonia-N concentrations of RPAAs and RPF by mixed rumen microorganisms are summarized in Table 3. The pattern of total VFA concentrations between cows fed with basal diet and RPAAs and RPF diet were similar. The cows fed diet containing RPAAs and RPF diet trended a higher VFA at $24 \mathrm{~h}(86.05 \mathrm{mM})$ and $48 \mathrm{~h}(101.30 \mathrm{mM})$ compared to controls (24 h: $67.98 \mathrm{mM}, 48 \mathrm{~h}: 99.01 \mathrm{mM}$ ). Ammonia-N concentrations between basal diet group and RPAAs and RPF treated group were not affected. Diets containing 7.5\% tallow fed to finishing cattle (Bogges et al., 1987) tended to lower in total VFA concentrations. In contrast, Sutton et al. (1983) reported no change in the concentration of total VFA and ammonia- $\mathrm{N}$ in sheep fed supplemental fat $(3 \%$ linseed oil, $3 \%$ coconut oil). Our study observed no great effect on total VFA and ammonia-N concentrations by supplementing RPAAs and RPF.

\section{In vivo dairy dry matter intake, milk production and milk composition \\ Dairy dry matter intake of Holstein dairy cows fed}

Table 2. Effects of supplementation of RPAAs and RPF on ruminal $\mathrm{pH}$ and $\mathrm{DMD}$, in vitro

\begin{tabular}{|c|c|c|c|c|c|c|c|c|}
\hline \multirow{2}{*}{$\begin{array}{l}\text { Time } \\
\text { (h) }\end{array}$} & \multicolumn{4}{|c|}{ Ruminal pH } & \multicolumn{4}{|c|}{ DMD (\%) } \\
\hline & Control $^{1}$ & Treatment $^{2}$ & SEM & $\mathrm{p}$ value & Control & Treatment & SEM & $\mathrm{p}$ value \\
\hline 3 & 6.33 & 6.38 & 0.02 & 0.12 & 29.93 & 30.93 & 1.08 & 0.55 \\
\hline 6 & 6.10 & 6.13 & 0.04 & 0.64 & 33.97 & 37.07 & 1.05 & 0.30 \\
\hline 12 & 5.74 & 5.73 & 0.01 & 0.59 & 43.78 & 44.28 & 0.56 & 0.58 \\
\hline 24 & 5.48 & 5.46 & 0.02 & 0.52 & 53.12 & 53.95 & 0.68 & 0.53 \\
\hline 48 & 5.43 & 5.44 & 0.01 & 0.69 & 55.21 & 56.11 & 0.69 & 0.46 \\
\hline
\end{tabular}

RPAAs, ruminally protected amino acids; RPF, ruminally protected fat; DMD, dry matter digestibility; SEM, pooled standard error of mean; RPLys, ruminally protected lysine; RPMet, ruminally protected methionine.

${ }^{1}$ Without supplementation of RPAAs and RPF.

${ }^{2} 2.71 \%$ of PRLys, $0.90 \%$ of PRMet, and $3.62 \%$ of RPF was incubated with $200 \mathrm{~mL}$ rumen inoculums at $39 \pm 0.5^{\circ} \mathrm{C}$ incubator for $48 \mathrm{~h}$. 
Table 3. Effects of supplementation of RPAAs and RPF on ruminal total VFA and ammonia-N concentrations, in vitro

\begin{tabular}{|c|c|c|c|c|c|c|c|c|}
\hline \multirow{2}{*}{$\begin{array}{l}\text { Time } \\
\text { (h) }\end{array}$} & \multicolumn{4}{|c|}{ Total VFA $(\mathrm{mM})$} & \multicolumn{4}{|c|}{ Ammonia-N (mg/dL) } \\
\hline & Control $^{1}$ & Treatment $^{2}$ & SEM & $\mathrm{p}$ value & Control & Treatment & SEM & $\mathrm{p}$ value \\
\hline 3 & 50.29 & 4960 & 22.18 & 0.74 & 6.42 & 6.40 & 0.30 & 0.96 \\
\hline 6 & 87.10 & 86.71 & 34.68 & 0.35 & 9.01 & 9.72 & 0.35 & 0.27 \\
\hline 12 & 58.64 & 56.52 & 29.10 & 0.43 & 11.85 & 12.25 & 1.15 & 0.82 \\
\hline 24 & 67.98 & 86.05 & 45.03 & 0.12 & 18.88 & 17.15 & 0.61 & 0.13 \\
\hline 48 & 99.01 & 101.30 & 51.55 & 0.42 & 14.59 & 15.53 & 0.16 & 0.35 \\
\hline
\end{tabular}

RPAAs, ruminally protected amino acids; RPF, ruminally protected fat; VFA, volatile fatty acid; SEM, pooled standard error of mean; RPLys, ruminally protected lysine; RPMet, ruminally protected methionine.

${ }^{1}$ Without supplementation of RPAAs and RPF.

${ }^{2} 2.71 \%$ of PRLys, $0.90 \%$ of PRMet, and $3.62 \%$ of RPF was incubated with $200 \mathrm{~mL}$ rumen inoculums at $39 \pm 0.5^{\circ} \mathrm{C}$ incubator for $48 \mathrm{~h}$.

control diet (basal diet) and treatment diet (basal diet+ RPAA and RPF) were not significantly different (Table 4). Wang et al. (2004) reported that DMI linearly decreased with dietary supplementation of fat in lactating cows. Schauff and Clark (1992) also found a similar tendency of decreasing DMI when cows were fed rations containing 3, 6 , or $9 \%$ of protected fat. However, the rations supplemented with fat would not necessarily cause the decrease of DMI during early lactation. According to Lee et al. (2008), the dietary supplementation with RPAAs did not affect DMI in lactating cows $(p>0.05)$. Under the condition of this study, DMI was also not affected by supplementation of RPAAs and RPA.

Milk yield and $4 \%$ fat corrected milk (FCM) were higher when cows were fed a diet containing RPAAs and
RPF in this study $(\mathrm{p}<0.001, \mathrm{p}<0.05)$ (Table 4). Depeters and Cant (1992) reported that supplementation of dairy rations with more than $2 \%$ added fat often improved milk yield. Sarwar et al. (1991) reported an increase of milk yield and $4 \%$ FCM in cows fed diets supplemented with Ca salts of fatty acid. Many researchers (Schwab et al., 1989; Chapoutot et al., 1992; Robinson et al., 1992) have indicated that milk yield and 4\% FCM increased with dietary supplementation of RPAAs.

The average fat $(\mathrm{p}<0.05)$, protein $(\mathrm{p}<0.001)$ and MUN $(p<0.05)$ contents in milk from cows fed RPAAs and RPF were higher than those of control (Table 4).

This is supported by an animal trial (Canale et al., 1990) where fat and protein contents in milk were noted higher in dairy cows fed the diets containing RPAAs and fat. Similar

Table 4. Effect of RPAAs and RPF supplementation on DM intake, milk yield and milk composition in mid-lactating Holstein-Frisian dairy cows

\begin{tabular}{|c|c|c|c|c|}
\hline Items & Control $^{1}$ & Treatment $^{2}$ & SEM & $\mathrm{p}$ value \\
\hline & \multicolumn{4}{|c|}{ 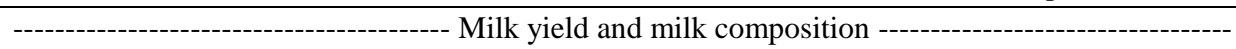 } \\
\hline DM intake $(\mathrm{kg})$ & 23.06 & 22.92 & 1.08 & 0.082 \\
\hline Milk yield (kg) & 30.52 & $33.29 * *$ & 0.34 & 0.0002 \\
\hline $4 \%$ FCM $(\mathrm{kg})$ & 29.73 & $32.63 *$ & 0.55 & 0.007 \\
\hline Milk fat (\%) & 3.73 & 3.87 & 0.07 & 0.16 \\
\hline Milk fat (kg) & 1.14 & $1.28 *$ & 0.02 & 0.002 \\
\hline Milk protein $(\%)$ & 3.02 & 3.05 & 0.02 & 0.47 \\
\hline Milk protein $(\mathrm{kg})$ & 0.92 & $1.02 * *$ & 0.01 & 0.0001 \\
\hline MUN (mg/dL) & 12.27 & $16.68 *$ & 0.86 & 0.005 \\
\hline DM intake $(\mathrm{kg} / \%)$ & -5.32 & -6.21 & 1.41 & 0.42 \\
\hline Milk yield (kg/\%) & -5.61 & $-1.86^{*}$ & 1.05 & 0.03 \\
\hline $4 \%$ FCM $(\mathrm{kg} / \%)$ & -4.54 & -0.98 & 1.81 & 0.22 \\
\hline Milk fat $(\%)$ & +5.78 & +5.05 & 1.62 & 0.77 \\
\hline Milk fat $(\mathrm{kg} / \%)$ & -0.28 & +3.54 & 1.87 & 0.19 \\
\hline Milk protein $(\%)$ & +0.99 & +1.76 & 0.84 & 0.58 \\
\hline Milk protein $(\mathrm{kg} / \%)$ & -4.88 & $+0.04 *$ & 1.11 & 0.01 \\
\hline MUN (mg/dL/\%) & -13.55 & -6.49 & 6.43 & 0.46 \\
\hline
\end{tabular}

RPAAs, ruminally protected amino acids; RPF, ruminally protected fat; DM, dry matter; SEM, pooled standard error of mean; FCM, fat corrected milk; MUN, milk urea nitrogen; RPLys, ruminally protected lysine; RPMet, ruminally protected methionine.

${ }^{1}$ Without supplementation of RPAAs and RPF (-, decrease rates; +, increase rates).

${ }^{2}$ Control group fed basal diet only (no addition of RPAAs and RPF), and the treatment group fed basal diet with $50 \mathrm{~g}$ of RPAAs (50\% of RPLys and RPMet, [3:1 ratio]) and $50 \mathrm{~g}$ of RPF ( $98 \%$ of RPF ) twice a day (total $100 \mathrm{~g}$ of each RPAAs and RPF/d).

Significantly difference between control and treatment $(* \mathrm{p}<0.05, * * \mathrm{p}<0.001)$ 
results were reported by Sloan et al. (1989). MUN concentration were higher $(16.68 \mathrm{mg} / \mathrm{dL})$ in dairy cows fed RPAAs and RPA compared to control (12.27 mg/dL), ( $<<0.05)$. However, according to Roseler et al. (1993), the suitable MUN concentration for Holstein dairy cow is between $12 \mathrm{mg} / \mathrm{dL}$ to $18 \mathrm{mg} / \mathrm{dL}$ which is where the present results ranged.

With an index against as $0 \%$ (Table 4), decrease rate of milk yield $(-1.86 \%)$ and milk protein $(0.04 \%)$ were significantly lower $(\mathrm{p}<0.05)$ in cows fed RPAAs and RPF than when cows were fed basal (Control) diet (milk yield, $-5.61 \%$; milk protein, $-4.88 \%$ ). The variations of milk yield, $4 \%$ FCM, milk fat, milk fat yield, MUN, milk protein, milk protein yield in dairy cows fed diets containing RPAAs and RPF or basal diet are shown in Figure 1A, 1B, 1C, 1D, 1E, $1 \mathrm{~F}$, and $1 \mathrm{G}$. Cows fed with diet containing RPAAs and RPF were linearly higher in milk yield $(\mathrm{kg} / \%)$, milk fat yield $(\mathrm{kg} / \%)$, milk protein yield $(\mathrm{kg} / \%)$ and MUN (mg/dL) during whole experimental period (6 wk), (Figure 1A, 1D, $1 F$ and $1 G),(p>0.05)$. It is known that the milk fat content is higher when cows are fed RPAAs (Robinson et al., 1992). In addition, supplementation of RPF to lactating cows increased milk yield and fat content in milk (Mattias et al., 1982).

The results of this study demonstrate that dietary supplementation of RPAAs and RPF has a positive effect on milk yield and milk composition including 4\% FCM, fat, protein in mid-lactating dairy cows without adversely affecting ruminal fermentation.

According to previous studies, supplementation of RPAAs or RPF may positively affect milk yield and milk composition. However, no report has been published on the effect of supplementing RPAAs and RPF together on ruminal performances and lactation responses in midlactating dairy cows. In particular, we found that the milk protein content was higher when cows were fed RPAAs and RPF together compared to supplementing RPAAs or RPF individually.

However, it is not yet known what percentage of RPAAs and RPA are required to affect milk yield and milk composition. Therefore, the question of digestion and absorption of RPAAs and RPF in the abomasum requires further study.

The best strategy for dairy farmers to increase their

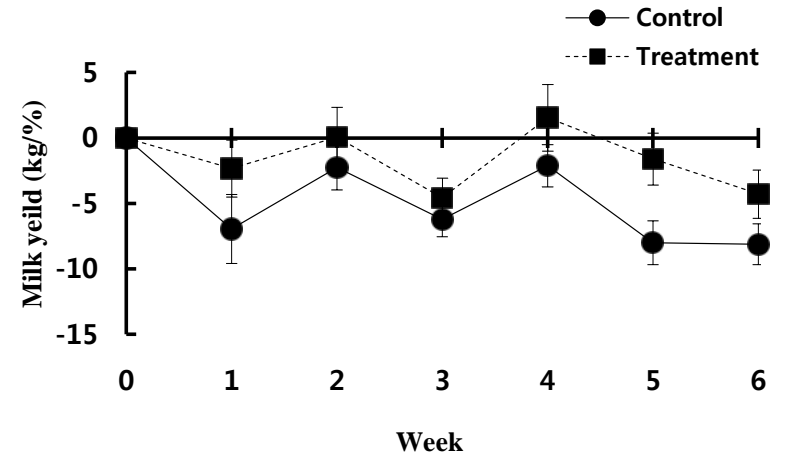

(A)

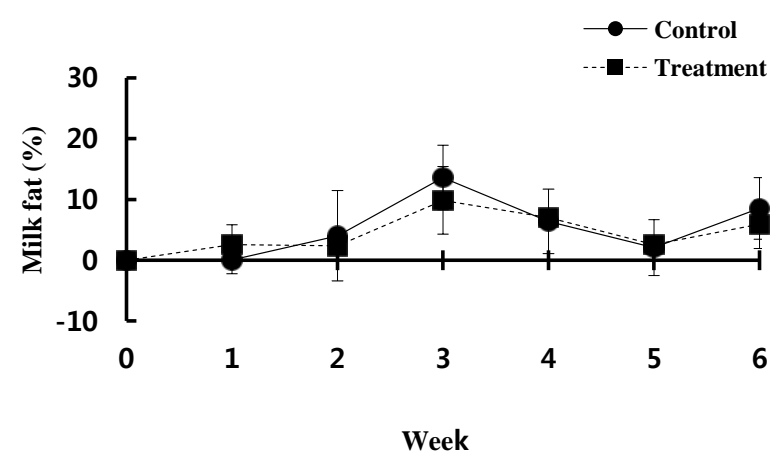

(C)

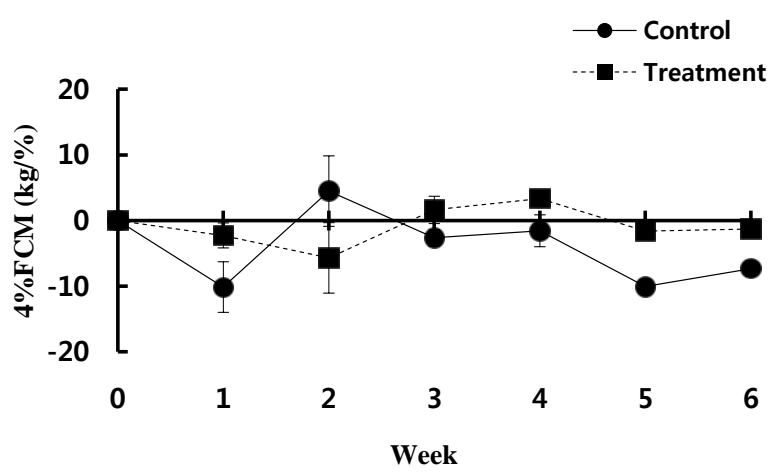

(B)

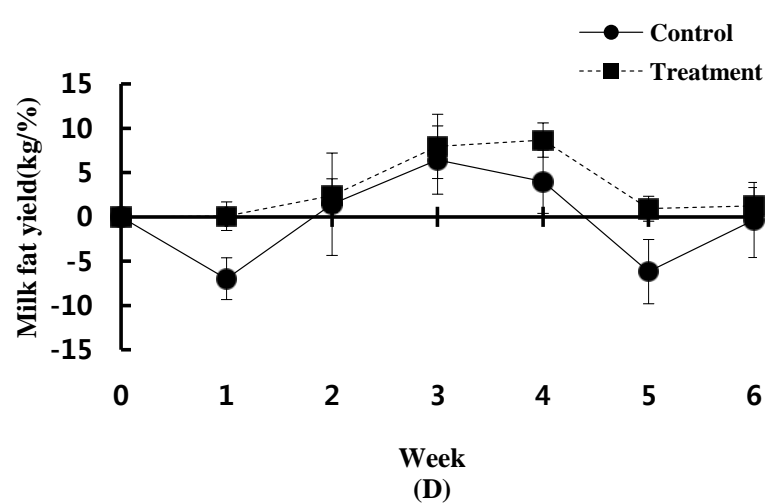

(D)

Figure 1. i) Effect of RPAAs and RPF supplementation on milk (A) yield (kg/\%), (B) 4\% fat corrected milk (FCM) (kg/\%), (C) fat (\%), (D) fat yield $(\mathrm{kg} / \%),(\mathrm{E})$ protein $(\%),(\mathrm{F})$ protein yield $(\mathrm{kg} / \%),(\mathrm{G}) \mathrm{MUN}$ (milk urea nitrogen) yield (mg/dL/\%) of Holstein-Frisian dairy cows (Index against $0 \%$ ). Control group fed basal diet only (no addition of RPAAs and RPF), and the treatment group fed basal diet with $50 \mathrm{~g}$ of RPAAs (50\% of RPLys and RPMet [3:1 ratio]) and $50 \mathrm{~g}$ of RPF ( $98 \%$ of RPF ) twice a day (total $100 \mathrm{~g}$ of each RPAAs and RPF/d). RPAAs, ruminally protected amino acids; RPF, ruminally protected fat; RPLys, ruminally protected lysine; RPMet, ruminally protected methionine. 


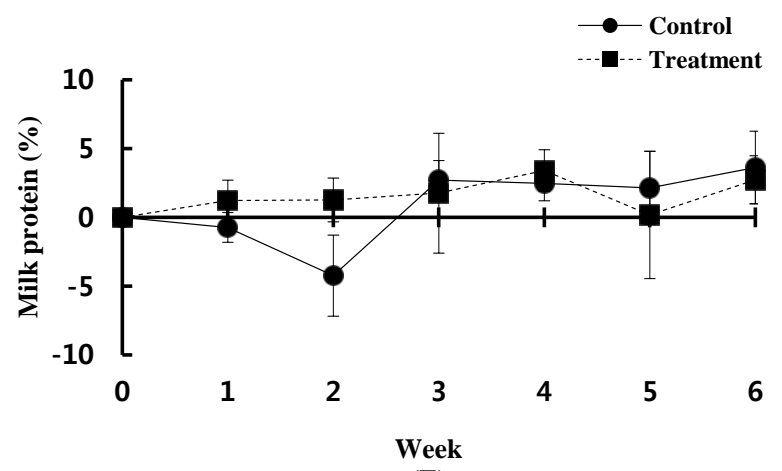

(E)

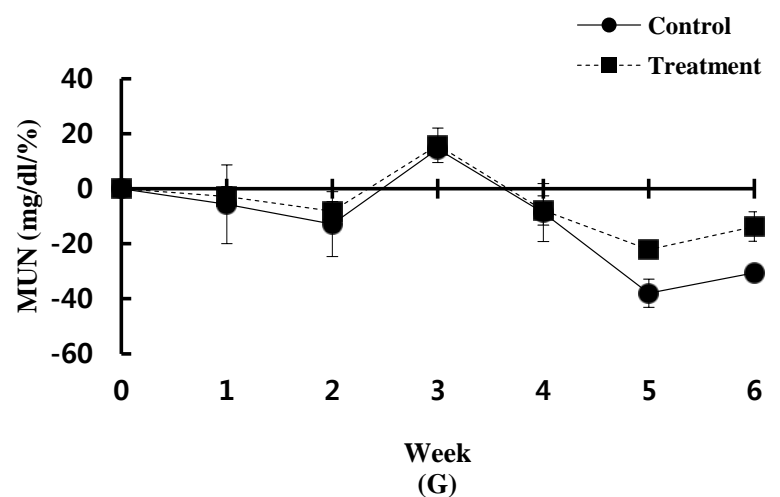

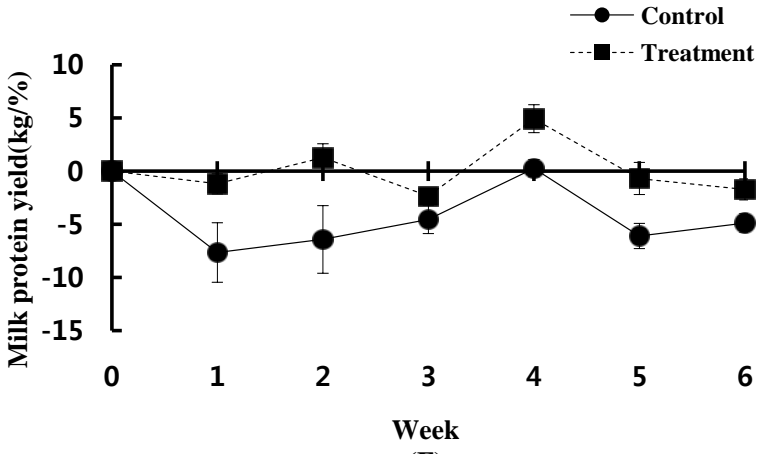

(F)

Figure 1. ii) Effect of RPAAs and RPF supplementation on milk (A) yield (kg/\%), (B) 4\% fat corrected milk (FCM) (kg/\%), (C) fat (\%), (D) fat yield (kg/\%), (E) protein (\%), (F) protein yield (kg/\%), (G) MUN (milk urea nitrogen) yield (mg/dL/\%) of Holstein-Frisian dairy cows (Index against 0\%). Control group fed basal diet only (no addition of RPAAs and RPF), and the treatment group fed basal diet with $50 \mathrm{~g}$ of RPAAs (50\% of RPLys and RPMet [3:1 ratio]) and $50 \mathrm{~g}$ of RPF ( $98 \%$ of RPF ) twice a day (total $100 \mathrm{~g}$ of each RPAAs and RPF/d). RPAAs, ruminally protected amino acids; RPF, ruminally protected fat; RPLys, ruminally protected lysine; RPMet, ruminally protected methionine.

income is through genetic improvement and the optimization of nutrient utilization of their cows. Feed additives are one of the quicker methods to increase milk yield and milk composition. Therefore, supplementation of RPAAs and RPF together might increase the profits from dairy farms.

\section{REFERENCES}

AOAC. 1984. Official Method of Analysis (14th Ed.). Association of Official Analytical Chemists. Washington, DC, USA

Bines, J. A., P. E. Brumby, J. E. Storry, R. J. Fulford, and G. J. Braithwaite. 1978. The effect of protected lipids on nutrient intake, blood and rumen metabolites and milk secretion in dairy cows during early lactation. J. Agric. Sci. 91:135-150.

Boggs, D. L., W. G. Bergen, and D. R. Hawkins. 1987. Effects of tallow supplementation and protein withdrawal on ruminal fermentation, microbial synthesis and site of digestion. J. Anim. Sci. 64:907-914.

Briggs, P. K., J. P. Hogen, and R. L. Reid. 1957. Effect of volatile fatty acid, lactic acid and ammonia on rumen $\mathrm{pH}$ in sheep. Aust. J. Agric. Res. 8:674-690.

Canale, C. J., L. D. Muller, H. A. McCahon, T. J. Whitsel, G. A.
Varga, and M. J. Lormore. 1990. Dietary fat and ruminally protected amino acids for high producing dairy cows. J. Dairy Sci. 73:135-141.

Chalupa, W., B. Vecchiarelli, A. E. Elser, D. S. Kronfeld, D. Sklan, and D. L. Palmquist. 1986. Rumenal fermentation in vivo as influenced by long chain fatty acids. J. Dairy Sci. 69:12931301.

Chaney, A. L. and E. P. Marbach. 1962. Modified reagent for determination of urea and ammonia. Clin. Chem. 8:130-132.

Chapoutot, P., P. Schmidely, D. Sauvant, J. C. Robert, and B. Sloan. 1992. Influence of a ruminally protected blend of methionine and lysine on the dairy cow nutrition and production. J. Dairy Sci. 75(Suppl. 1):199(abstr.).

Depeters, E. J. and J. P. Cant. 1992. Nutritional factors influencing the nitrogen composition of milk: A review. J. Dairy Sci. 72:2043-2070.

Donkin, S. S., G. A. Varga, T. F. Sweeney, and L. D. Muller. 1989. Rumen protected methionine and lysine: Effects on animal performance, milk protein yield and physiological measure. J. Dairy Sci. 72:1484-1491.

Fuller, M. F., R. McWilliam, T. C. Wang, and L. R. Giles. 1989. The optimum dietary amino acid pattern for growing pigs. Br. J. Nutr. 62:255-267.

Goering, H. K. and Van Soest. 1980. Forage Fiber Analysis. 
(Apparatus, Reagents, Procedures and Some Application). Agricultural Hand Book. No. 379, ARS-USDA, Washington, DC, USA.

Hill, G. M. and J. W. West. 1991. Rumen protected fat in kline barley or corn diets for beef cattle: Digestion, physiological, and feedlot responses. J. Anim. Sci. 69:3376-3388.

Kumar, S., S. S. Dagar, S. K. Sirohi, R. C. Padhyay, and A. K. Puniya. 2013. Microbial profiles, in vitro gas production and dry matter digestibility based on various rations of roughage to concentrate. Ann. Microbiol. 63:541-545.

Izumi, K., C. Kikuchi, and M. Okamoto. 2000. Effect of rumen protected methionine on lactational performance of dairy cows. Asian Australas. J. Anim. Sci. 13:1235-1238.

Lee, J. M., I. S. Nam, and J. H. Ahn. 2008. Effects of supplementation of ruminally protected amino acid on in vitro ruminal parameters and milk yield and milk composition of dairy cows in mid-lactation. J. Anim. Sci. Technol. 50:199-208.

Macleod, G. K., Y. Yu, and L. R. Schaeffer. 1977. Feeding value of protected animal tallow for high yielding dairy cows. J. Dairy. Sci. 60:726-738.

Mattias, J. E., G. J. Ruegsegger, L. H. Schultz, and W. J. Tyler. 1982. Effect of feeding animal fat to dairy cows in early lactation. J. Dairy Sci. 65(Suppl. 1):151.

Ngidi, M. E., S. C. Loerch, F. L. Fluharty, and D. L. Palmquist. 1990. Effects of calcium soaps of long chain fatty acids on feedlot performance, carcass characteristics and ruminal metabolism of steers. J. Anim. Sci. 68:2555-2565.

Palmquist, D. L. and H. R. Conard. 1978. High fat ration for dairy cows. Effects on feed intake, milk and fat production, and plasma metabolites. J. Dairy Sci. 61:890-901.

Robinson, P. H., W. Chalapa, W. Julien, K. Sato, H. Suzuki, and R. E. McQueen. 1992. Supplemental rumen-protected amino acids for early lactation dairy cattle. J. Dairy Sci. (Suppl.1):199(abstr).

Roseler, D. K., J. D. Feruson, C. J. Sniffen, and J. Herrema. 1993. Dietary protein degradability effect on plasma and milk urea nitrogen and milk nonprotein nitrogen in Holstein cows. J. Dairy Sci. 76:525-532.

Sarwar, M., J. L. Firkins, and M. L. Estridge. 1991. Effect of replacing neutral detergent fiber of forage with soy hull and corn gluten feed for dairy heifers. J. Dairy Sci. 74:1006-1017.
SAS. 1996. User's Guide: Statistics, Version 6.12 Edition. SAS Inst., Inc., Cary, NC, USA.

Schingoethe, D. J., D. P. Casper, C. Yang, D. J. Illg, J. L. Sommerfeldt, and C. R. Mueller. 1988. Lactational response to soybean meal, heated soybean meal, and extrued soybeans with ruminally protected methionine. J. Dairy Sci. 71:173-180.

Schwab, C. G., C. K. Bozak, N. L. Whitehouse, and V. M. Olsin. 1989. Extent of lysine limitation in mid lactation cows fed a corn-based ration. J. Dairy Sci. 72(Suppl. 1):506(Abstr.).

Sehauff, D. J. and J. H. Clark. 1992. Effect of feeding diets containing calcium salts of long-chain fatty acids to lactating dairy cows. J. Dairy Sci. 75:2990-3002.

Sharma, H. R., J. R. Inaglls, and J. A. Mckirdy. 1978. Replacing barley with protected tallow in ration of lactating holstein cows. J. Dairy Sci. 61:574-583.

Sloan, B. K., J. C. Robert, and J. Mathe. 1989. Influence of dietary crude protein of coconut plus or minus inclusion or rumenprotected amino acids (RAA) on the early lactation performance of heifers. J. Dairy Sci. 72(Suppl.1):506(Abstr.).

Sutton, J. D., R. Knight, A. B. McAllan, and R. H. Smith. 1983. Digestion and synthesis in the rumen of sheep given diets supplemented with free or protected oils. Br. J. Nutr. 49:419432.

Tilly, J. M. A. and R. A. Terry. 1963. A two stage technique for in vitro digestion of forage crop. Grass. Forage Sci. 18:104-111.

Veira, D. M., J. R. Seoane, and J. G. Proulx. 1991. Utilization of grass silage by growing cattle: Effect of a supplement contacting ruminally protected amino acids. J. Anim. Sci. 69: 4703-4709.

Wang, A. S., D. E. Jan, K. J. Chen, D. W. Yang, and Y. K. Fan. 2004. Dietary supplementation of fat increased milk percentage without affecting ruminal characteristics in Holstein cows in a warm tropical environment. Asian Australas. J. Anim. Sci. 17:213-220.

Wrenn, T. R., J. Bitman, R. A. Waterman, J. R. Weyant, D. L. Wood, L. L. Strozinski, and N. W. Hooven Jr. 1978. Feeding protected and unprotected tallow to lactating cows. J. Dairy Sci. 61:49-58.

Yang, Y. T., R. L. Baldwin, and J. Russell. 1978. Effect of long supplementation with lipids on lactating dairy cows. J. Dairy Sci. 60:180-188. 